\title{
DAMPAK PENERAPAN SERTIFIKASI PERDAGANGAN IKAN HIAS LAUT PADA KONDISI EKOSISTEM TERUMBU KARANG DAN KONDISI SOSIAL EKONOMI NELAYAN DI KEPULAUAN SERIBU
}

\author{
Idris dan Aar Mardesyawati \\ Yayasan Terumbu Karang Indonesia \\ Telp. (021) 7994912 \\ Email: idris@terangi.or.id
}

Diterima 6 September 2012 - Disetujui 23 November 2012

\begin{abstract}
ABSTRAK
Sertifikasi ikan hias diterapkan di Kepulauan Seribu pada 2003-2006 oleh MAC berdasarkan kebutuhan pembeli yang menginginkan ikan hias laut yang sehat dan ditangkap dengan cara yang tidak merusak lingkungan. Studi ini bertujuan untuk mengevaluasi dampak penerapan program sertifikasi perdagangan ikan hias laut terhadap kondisi ekosistem terumbu karang dan kondisi sosial ekonomi nelayan di Kepulauan Seribu. Studi ini dilaksanakan di Pulau Panggang, Kepulauan Seribu. Studi ini menggunakan tiga metode, yaitu diskusi kelompok terfokus (FGD), wawancara mendalam, dan kuisioner. Responden dalam studi ini terdiri dari kelompok nelayan dan pengepul ikan hias (belum dan sudah tersertifikasi), tokoh masyarakat, ketua kelompok nelayan, dan kepala keluarga dalam rumah tangga nelayan. Hasil studi menunjukkan bahwa sebanyak 73\% responden menyatakan kondisi terumbu karang di lokasi tangkap masih dalam kategori baik. Sementara, sebanyak 58\% responden menyatakan kondisi ikan hias cenderung meningkat. Pada aspek sosial dan ekonomi, sebanyak $62 \%$ responden merasa lebih aman dalam menangkap ikan karena tidak melanggar hukum, sebanyak 96\% responden menyatakan sangat baik dalam hal penyelesaian masalah melalui kelompok, dan sebanyak $96 \%$ responden menyatakan memiliki kondisi fisik yang lebih baik. Namun, hanya sebanyak $42 \%$ responden yang menyatakan ada perbaikan harga jual ikan hias dari nelayan. Kesimpulan yang dapat diambil dari studi ini adalah program ini bisa mengubah persepsi masyarakat untuk menggunakan alat tangkap ramah lingkungan untuk mengurangi kerusakan ekosistem terumbu karang. Secara sosial, keamanan dan kesehatan nelayan cenderung meningkat. Secara ekonomi, program ini tidak memberikan perbaikan atau peningkatan harga ikan hias pada tingkat nelayan.
\end{abstract}

Kata Kunci: nelayan ikan hias, sertifikasi, sosial ekonomi, Kepulauan Seribu

\section{Abstract: Impact of Implementation Marine Ornamental Fish Certification on Coral Reefs Ecosystem and Socio Economic of Fishers Condition in theKepulauan Seribu. By: Idris and Aar Mardesyawati.}

Marine ornamental fish certification was implemented in Seribu Islands at $2003-2006$ by MAC on the need of buyers who want a healthy marine ornamental fish and non destructive fishing. This study aimed to evaluate impact of implementation of certification program of marine ornamental fish on coral reef ecosystem and social economic of fishers condition in Seribu Islands. The study was conducted in Panggang Island, Seribu Islands. The study was using three methods namely focus group discussions (FGD), in-depth interviews, and questionnaires. Number of respondents in the study were 44 respondents consist of a group of fishers and collectors of marine ornamental fish (certified and non certified), public figures, chief of the fishers group, and the head of fishers household. The result of this study was showed about $73 \%$ of respondents said the condition of coral reefs in fishing ground still in good category. Meanwhile, about 58\% respondent said the condition of population marine ornamental fish is increase. In the social and 
economic aspects, about $62 \%$ of respondents felt more secure to collecting fish because they did not against the law, about $96 \%$ of respondents stated very well in terms of problem solving with group, and as $96 \%$ of respondents stated they have a better healthy condition. However, only about $42 \%$ of respondents was said the prices of marine ornamental fishes are increase. This study concluded that the program could changed the perception of community in Panggang Island that using environmental-friendly fishing gear can reduce the destruction of coral reefs ecosystem. However, economic benefit of the certification program was not making improvement and increasing the prices of marine ornamental fishes.

Keywords: marine ornamental fisher, certification, socio-economic, Seribu Islands

\section{PENDAHULUAN}

Perdagangan ikan hias laut dunia dimulai pada tahun 1930-an, dan meningkat tajam sejak tahun 1950-an dengan penambahan lokasi penangkapan, seperti Hawai dan Filipina (Wabnitz et al., 2003). Sekitar 1.471 jenis ikan hias diperdagangkan di dunia, dengan perkiraan jumlah sebanyak 20 hingga 24 juta ekor. Jenis ikan jae-jae (Pomacentrus viridis) dan ikan badut (Amphiprion ocellaris) merupakan ikan yang terbanyak diperdagangkan (Wabnitz et al., 2003). Ikan hias air laut masih mengandalkan penangkapan alam, hanya kurang dari $1 \%$ saja yang telah dibudidayakan (Wood, 2001).

Di Indonesia perdagangan ikan hias laut dimulai pada tahun 1960-an, dengan lokasi penangkapan yang pertama adalah Kepulauan Seribu. Saat ini Indonesia merupakan negara pengekspor ikan hias laut terbesar, bersama dengan Filipina. Pengunaan sianida sebagai alat tangkap, baik ikan hias maupun ikan konsumsi, mulai marak dan masif digunakan pada tahun 1980-an hingga 1990-an. Penggunaan sianida sebagai alat tangkap ikan hias dianggap cukup efektif dan murah pada masanya. Penangkapan ikan hias dengan sianida menimbulkan kerusakan terhadap ekosistem terumbu karang.

Hasil penelitian yang dilakukan oleh Suku Dinas Perikanan dan Kelautan Kepulauan Seribu (2007) menunjukkan persen penutupan berkisar antara 0,38-48,25\%, dengan rerata $24,69 \%$. Lokasi pengamatan yang terletak paling selatan adalah P. Bidadari, dengan persen penutupan karang hidupnya hanya $0,38 \%$.
Ekosistem P. Bidadari bisa dikatakan bukan lagi ekosistem terumbu karang (Sudin Kanla Kep. Seribu, 2007).

Pengelolaan pemanfaatan ikan hias laut dan biota terumbu karang lainnya di Kepulauan Seribu dimulai pada tahun 2004, salah satu cara dalam mengelola ikan hias laut dan biota terumbu karang adalah dengan program sertifikasi yang meliputi peningkatan kapasitas sumber daya manusia, cara-cara tangkap yang ramah lingkungan dan pengaturan penangkapan, dan juga konservasi ekosistem terumbu karang. Sertifikasi ikan hias diterapkan di Kepulauan Seribu pada 2003 oleh MAC berdasarkan kebutuhan pembeli yang menginginkan ikan hias laut yang sehat dan ditangkap dengan cara yang tidak merusak lingkungan. Studi ini bertujuan untuk mengevaluasi dampak penerapan program sertifikasi perdagangan ikan hias laut pada kondisi ekosistem terumbu karang dan kondisi sosial ekonomi nelayan di Kepulauan Seribu.

\section{METODOLOGI}

\section{Waktu dan Lokasi Penelitian}

Waktu pengumpulan data dilakukan pada tanggal 17-29 Desember 2008 di Pulau Panggang, Kelurahan Pulau Panggang Kabupaten Administratif Kepulauan Seribu.

\section{Metode Penelitian}

Metode yang digunakan, yaitu diskusi kelompok terfokus (Focus Group discussion /FGD dan wawancara mendalam (Indepth Interview)alat bantu penelitian yang digunakan 
adalah kuesioner. Kondisi terumbu karang dan ikan dinilai dengan menggunakan persepsi responden yang terjun langsung di lapangan. Persepsi ini terhadap kondisi terumbu karang dibagi menjadi 4 kategori yaitu :

1. Kategori sangat baik adalah banyak terumbu karang hidup yang menutupi dasar perairan tanpa terlihat adanya karang mati;

2. Kategori baik adalah ada terlihat sedikit karang mati diantara hamparan karang hidup yang menutupi dasar perairan;

3. Kategori sedang adalah terlihat ada sebagian karang hidup dan sebagian lagi karang mati;

4. Kategori buruk adalah lebih banyak terlihat karang mati dari pada karang hidup yang menutupi dasar perairan.

Persepsi masyarakat terhadap kondisi ikan karang dibagi menjadi 3 kategori yaitu :

1. Kategori meningkat adalah hasil tangkapan diwilayah tangkap meningkat dan terlihat banyak juwana ikan disekitar terumbu karang dan padang lamun;

2. Kategori sama saja adalah hasil tangkapan tidak mengalami perubahan dari sebelum dan sesudah ada kegiatan sertifikasi;

3. Kategori menurun adalah hasil tangkapan menurun setelah adanya kegiatan sertifikasi ikan hias.

Jumlah responden dalam studi ini sebanyak 44 responden yang terdiri dari kelompok nelayan dan pengepul ikan hias (belum dan sudah tersertifikasi), tokoh masyarakat, ketua kelompok nelayan, dan kepala keluarga dalam rumah tangga nelayan.

a. FGD dilakukan sebanyak 4 kali kepada beberapa kelompok :

1. Nelayan ikan hias yang tersertifikasi;

2. Nelayan ikan hias yang belum tersertifikasi;

3. Pengepul ikan hias tersertifikasi dan yang belum tersertifikasi;

4. Tokoh masyarakat (perwakilan RT/RW, Kelurahan, tokoh masyarakat, tokoh agama, tokoh wanita, tokoh pemuda);

b. Wawancara mendalam dilakukan kepada :

1. Ketua kelompok nelayan penangkap ikan hias (KELONPIS);

2. Ketua kelompok perhimpunan nelayan ikan hias dan tanaman hias (PERNITAS);

3. Community organizer yayasan terumbu karang indonesia (TERANGI)

4. Nelayan ikan konsumsi.

c. Kuesioner Rumah Tangga Nelayan Ikan Hias :

Kuesioner disebarkan kepada 44 responden dari total populasi 72 anggota dari KELONPIS dan PERNITAS, baik yang tersertifikasi dan belum; sebagai kontrol dan variasi data diambil pula responden yang berasal dari luar kelompok. Kriteria responden adalah rumah tangga nelayan/ pengepul ikan hias dengan responden kunci kepala rumah tangga.

Tabel 1. Proporsi Responden.

Table 1. Proportion of Respondents.

\begin{tabular}{lcc} 
& Sertifikasi/Certified & Non Sertifikasi/Non Certified \\
\hline $\begin{array}{l}\text { Nelayan tergabung dalam kelompok/ } \\
\text { Fishers within group }\end{array}$ & 15 Responden (Respondents) & 10 Responden (Respondents) \\
$\begin{array}{l}\text { Nelayan tidak tergabung Kelompok/ } \\
\text { Fishers without group }\end{array}$ & 6 Responden (Respondents) & 5 Responden (Respondents) \\
Pengumpul ikan hias/Middlemen & 3 Responden (Respondents) & 5 Responden (Respondents) \\
\hline
\end{tabular}




\section{Analisa Data}

Analisa data tutupan terumbu karang Kepulauan Seribu untuk persepsi masyarakat, data tangkapan ikan hias, data wawancara mendalam dan FGD menggunakan microsoft excel 2003, sedangkan data kuisioner menggunakan software SPSS 13.

\section{PERSEPSI TERHADAP KONDISI TERUMBU KARANG DAN KELIMPAHAN IKAN HIAS}

\section{a. Perbaikan Kondisi Terumbu Karang}

Kondisi terumbu karang dilihat dengan menggunakan persepsi masyarakat dan dibandingkan dengan hasil survai kondisi terumbu karang yang sudah pernah dilakukan.

Pada Gambar 1 terlihat bahwa sekitar $4 \%$ responden menyatakan bahwa kondisi terumbu karang sangat baik, $73 \%$ menyatakan dalam kondisi baik, 20\% menyatakan dalam kondisi sedang dan $3 \%$ menyatakan dalam kondisi buruk. Berdasarkan hasil grafik diatas maka dapat dikatakan bahwa persepsi masyarakat terhadap perbaikan kondisi terumbu karang setelah adanya kegiatan sertifikasi cenderung menjadi baik. Hal ini sesuai juga dengan hasil penelitian Yayasan Terumbu Karang Indonesia (TERANGI) menunjukkan adanya peningkatan rerata persen penutupan karang hidup dari $32,9 \%$ (2004) menjadi 33,2\% (2005), dengan nilai indeks mortalitas berkisar antara 0,00-0,78 (2004) dan 0,00 - 0,87 (2005). Kekayaan marga yang berhasil teridentifikasi sebanyak 64 marga dari 18 suku karang keras (Estradivari et al., 2007).

\section{b. Kondisi Kelimpahan Ikan Hias}

Penangkapan ikan hias air laut merupakan penangkapan ikan yang amat selektif, yang didasarkan kepada pemesanan. Kebanyakan nelayan melakukan penangkapan untuk ikan-ikan hias yang memiliki nilai ekonomi tinggi, ini merupakan ancaman potensial terjadinya over-eksploitasi pada jenis tertentu (Wood, 1985; 2001). Sertifikasi ikan hias merupakan salah satu cara yang digunakan untuk mengontrol pemanfaatan berlebih dan sudah dilakukan sejak tahun 2003.

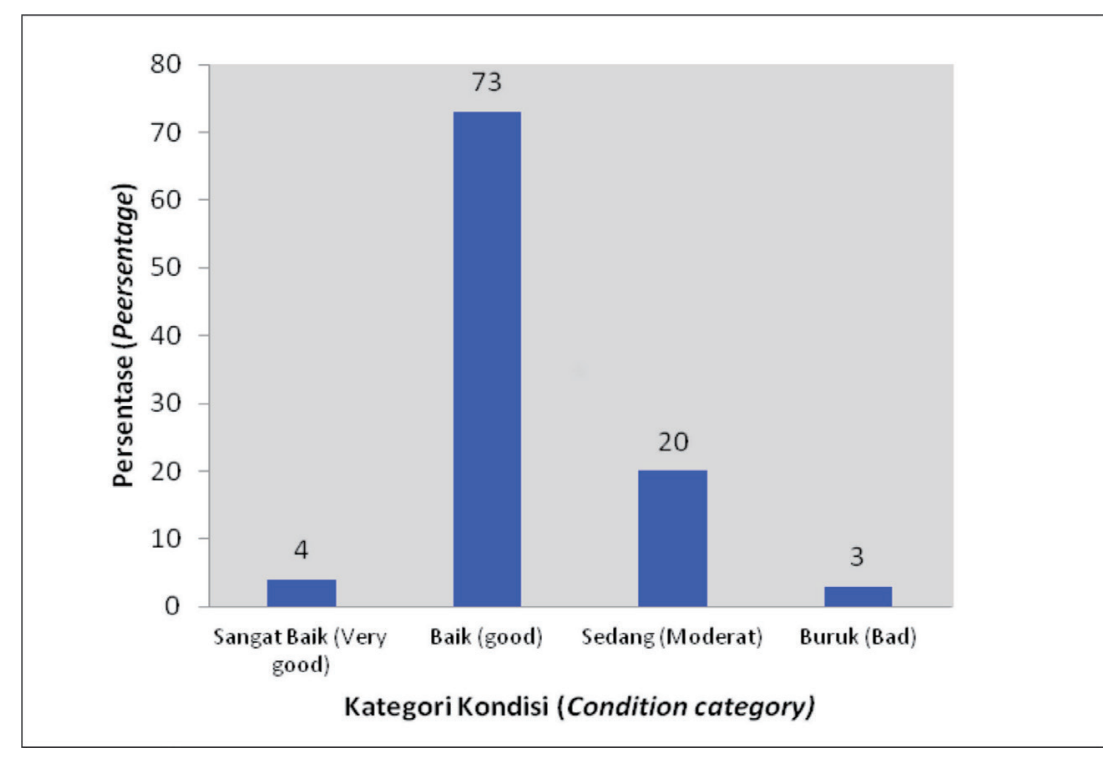

Gambar 1. Persentase Persepsi Responden Terhadap Kondisi Terumbu Karang Disekitar Wilayah Tangkap (Setelah Program Sertifikasi Berjalan).

Figure 1. Percentage of Respondents Perception to the Condition of Coral Around Fishing Grounds (After Certification Program) 


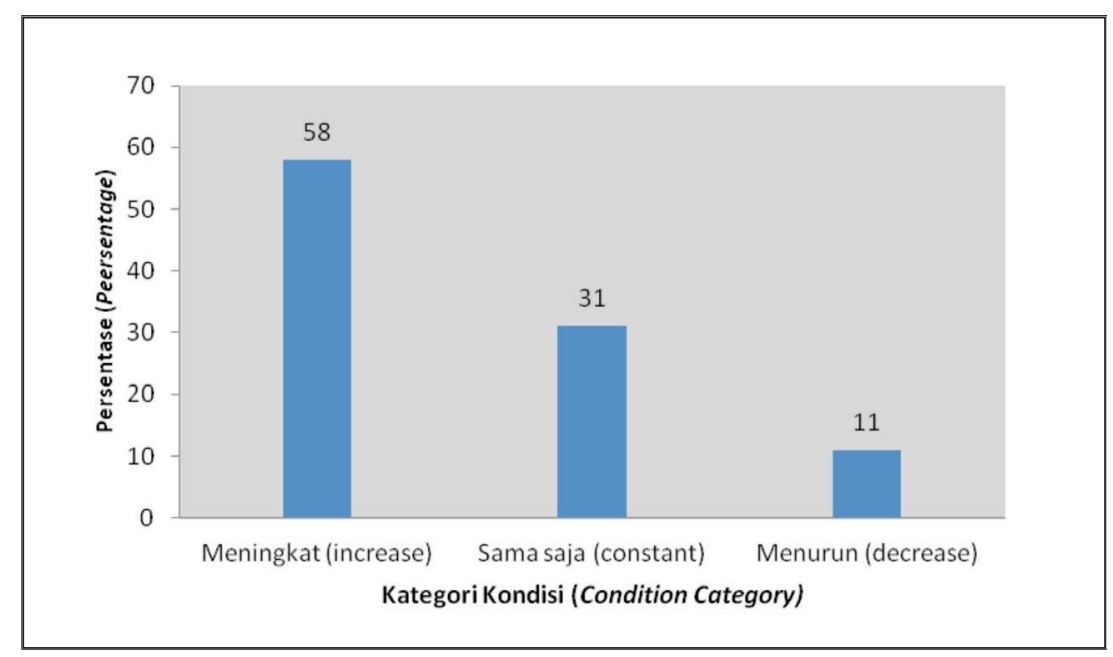

\section{Gambar 2. Persentase Persepsi Responden Terhadap Kondisi Ikan Diwilayah Tangkapan (Setelah Program Sertifikasi Berjalan). \\ Figure 2. Percentage of Respondents Perception to the Condition of Fish Population in Fishing Ground (After Certification Program).}

Persepsi masyarakat dalam penilaian kelimpahan ikan sebagai salah satu cara melihat keberhasilan program sertifikasi, hal ini dilihat dari persepsi masyarakat tentang kelimpahan ikan.

Pada Gambar 2 terlihat bahwa sekitar $58 \%$ responden menyatakan bahwa kelimpahan ikan meningkat, 31\% menyatakan biasa saja (tidak ada perubahan), 11\% menyatakan dalam kondisi menurun.

Berdasarkan beberapa kajian bahwa terjadi fluktuasi kelimpahan dan kekayaan jenis ikan karang baik secara spasial di setiap lokasi pengamatan maupun temporal dari tahun 2003 hingga 2007, namun hasil analisis sidik ragam memperlihatkan tidak ada perbedaan nyata pada struktur komunitas ikan karang di Kepulauan Seribu (Setyawan dan Nugroho, 2007). Kajian lainnya menyatakan bahwa hasil analisis ANOVA satu arah terhadap 10 jenis ikan dengan penangkapan tertinggi tidak berubah secara nyata terhadap kelimpahan ikan, namun secara keseluruhan menunjukkan kecenderungan kelimpahannya menurun (Widjoyo dan Idris, 2007).

\section{MASALAH HUKUM DAN EKONOMI}

Menurut pengakuan nelayan sebelumnya mereka ketakutan dan was-was jika ketahuan menangkap ikan hias, meskipun mereka tidak menggunakan racun sianida dalam menangkap ikan. Beberapa kasus sering terjadi penangkapan terhadap nelayan ikan hias yang menggunakan racun sianida seperti yang terjadi di Banten terhadap 12 nelayan yang ditangkap aparat kepolisian yang berasal dari Polda Banten (Seputar Banten, 2010). Setelah adanya program sertifikasi nelayan merasa aman dan tidak was-was lagi akan ditangkap petugas jika menangkap ikan hias. $\mathrm{Hal}$ ini terlihat dari grafik bahwa dampak program sertifikasi terhadap nelayan ikan hias adalah $62 \%$ menyatakan rasa aman dalam menangkap ikan tidak perlu khawatir akan ditangkap petugas.

Program sertifikasi mewajibkan adanya kelompok sebagai wadah nelayan dalam berkomunikasi dan menyelesaikan masalah. Kelompok akan membantu menyediakan peralatan memnagkap ikan dengan cara mencicil dan harga yang relatif murah dengan akses yang mudah. Hasilnya sebanyak $96 \%$ 
nelayan menyatakan cara mengatasi masalah lewat kelompok sangat baik dan sangat membantu.

Seorang responden mengatakan bahwa selama melakukan penangkapan ikan hias dengan sianida kesehatannya sering terganggu berupa sesak napas, kulit terasa panas dan cepat sekali merasa capek. Setalah adanya program seritifikasi yang melarang menggunakan racuan sianida dan memperkenalkan alat tangkap ramah lingkungan sebagain besar nelayan merasa kondisi fisik mereka lebih baik. Hal ini terlihat dari hasil survey dimana sebanyak $96 \%$ responden menyatakan kondisi fisik menjadi lebih baik.

Program ini hanya mampu meningkatkan harga jual ikan sebagian harga jual ikan di pasaran lokal dan internasional. Hal ini terlihat dari pernyataan responden bahwa $58 \%$ menyatakan tidak ada perbaikan harga. Namun ada $42 \%$ responden menyatakan ada perbaikan harga meskipun tidak signifikan yaitu sekitar Rp 200-300/ekor, sedangkan menurut nelayan peningkatan harga yang ideal adalah sebesar Rp 500/ekor. Jadi dapat dikatakan bahwa program sertifikasi masih belum mampu meningkatkan harga yang ideal bagi nelayan ikan hias.

\section{KELANJUTAN PROGRAM SERTIFIKASI}

Responden diberikan pertanyaan yang berkaitan dengan perlu atau tidaknya melanjutkan program sertifikasi ikan hias di wilayah mereka. Hal ini bertujuan untuk mengetahui seberapa penting program ini menurut responden.

Hasil penelitian terlihat pada grafik bahwa persepsi responden terhadap perlu atau tidaknya program sertifikasi dilanjutkan adalah $97 \%$, responden menyatakan perlu dilanjutkan dan 2,7\% menyatakan tidak perlu dilanjutkan. Alasan responden menginginkan program ini perlu dilanjutkan adalah karena 3 alasan dominan yaitu 23\% menyatakan agar lingkungan lebih bagus, $17 \%$ menyatakan menggunakan alat tangkap ramah lingkungan, dan $14 \%$ menyatakan agar masa depan lebih baik. Dalam hal ini terlihat bahwa dengan persentase responden memberikan alasan supaya lingkungan lebih baik mengindikasikan bahwa kesadaran masyarakat sudah meningkat terhadap lingkungan laut.

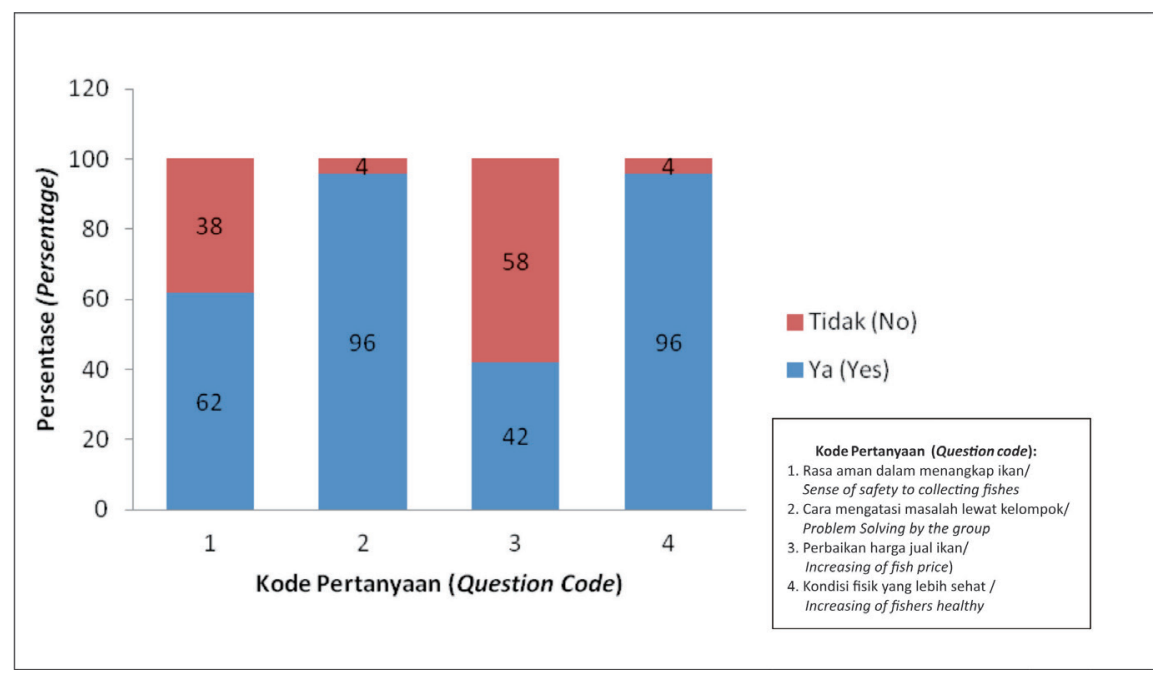

Gambar 3. Persentase Dampak Ekonomi dan Hukum Dari Program Sertifikasi. Figure 3. Percentage of the Economic and Legal Impact of the Certification Program. 


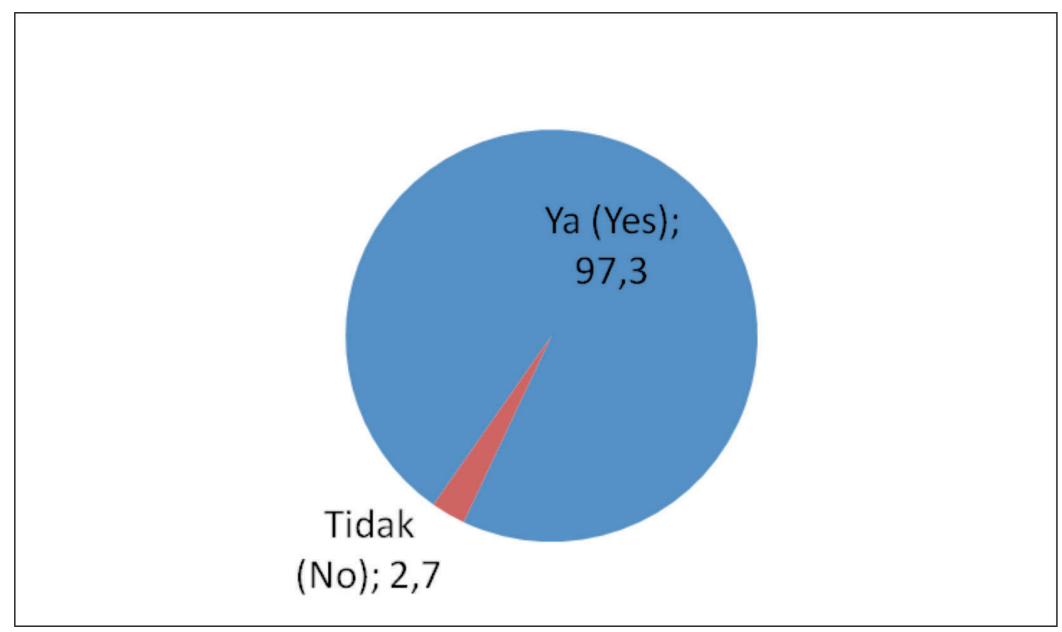

Gambar 4. Persentase Persepsi Responden Perlu Tidaknya Program Sertifikasi Dilanjutkan Figure 4. Percentage of Respondents Perception to Continued or no the Certification Program)

\section{PENUTUP}

Berdasarkan kajian ini dapat dikemukakan bahwa; (1) kondisi ekosistem terumbu karang diyakini semakin baik dalam lima tahun terakhir, (2) program sertifikasi memiliki manfaat langsung bagi nelayan dalam hal kesehatan meningkat, rasa aman dan pengenalan cara tangkap yang ramah lingkungan, (3) program sertifikasi belum mampu meningkatkan harga ikan yang ditangkap dengan cara ramah lingkungan dan pendapatan nelayan ikan hias secara keseluruhan, (5) kelompok sebagai media komunikasi mampu menjadi salah satu solusi dalam penyelesaian permasalahan nelayan terkait akses barang dan jasa, pengetahuan dan kesetaraan, (6) penegakan hukum yang tegas, oleh aparat kepolisian.

Saran yang dapat disampaikan berdasarkan hasil kajian ini adalah (1) meningkatkan harga dengan mengeluarkan kebijakan yang berpihak pada perbaikan kesejahteraan nelayan seperti keseragaman harga antar nelayan dan pengepul dan pembeli lokal, (2) penegakan hukum dalam bentuk patroli dan inspeksi mendadak secara berkala terhadap beberapa profesi baik ikan hias, ikan konsumsi dan biota terumbu karang lainnya, (3) pemerintah memfasilitasi pertemuan yang menyepakati bersama harga ikan hias dengan eksportir dan membentuk jaringan penjualan ikan hias yang mempermudah dan memperpendek jalur penjualan ikan hias

\section{DAFTAR PUSTAKA}

Estradivari, M. Syahrir, N. Susilo, S. Yusri dan S. Timotius. 2007. Terumbu karang Jakarta: pengamatan jangka panjang terumbu karang Kepulauan Seribu (2004-2005). Yayasan TERANGI. Jakarta.87 + ix h.

Idris, M. Prastowo, M. Syahrir, N. S. Widjoyo, R. E. Smara, S. Timotius. 2008. Peran Masyarakat Dalam Pengendalian Penggunaan Potassium sianida Sebagai Upaya Pengelolaan Terumbu Karang Kepulauan Seribu, Jakarta. Presentasi dalam Musyawarah Nasional Terumbu Karang tanggal 08 November 2008. Jakarta.

Marine Aquarium Council. 2001a. Core Collection, Fishing, and Holding. International performance standard for the marine aquarium trade. Marine Aquarium Council. . 2001b. Core ecosystem and fisheries management. International performance standard for the marine aquarium trade. Marine Aquarium Council. 
Seputar Banten. 2010. BTNUK Pandeglang Tangkap 12 Pencuri Ikan Hias.

Setyawan, E., dan N. S. Wijoyo. 2007. Struktur Dan Kelimpahan Komunitas Ikan Karang Di Perairan Kepulauan Seribu 2003, 2005, Dan 2007. Estradivari, E. Setyawan dan S. Yusri(Ed). Terumbu Karang Jakarta Pengamatan Jangka Panjang Terumbu Karang Kepulauan Seribu (2003-2007). Yayasan Terumbu Karang Indonesia. Jakarta. pp. 57-68.

Suku Dinas Perikanan dan Kelautan Kepulauan Seribu. 2007. Laporan Akhir Identifikasi Dan InventarisasiTerumbu Karang Kepulauan Seribu. Suku Dinas Perikanan dan Kelautan Kepulauan Seribu. Jakarta.

Wabnitz, Colette, Michelle Taylor, Edmund Green dan Tries Razak. 2003. From Ocean to Aquarium: The Global Trade in Marine Ornamental Species. UNEP - WCMC. Cambridge UK.
Widjoyo, N. S. dan Idris. 2006. Penangkapan Ikan Hias Hubunganya dengan Struktur Komunitas Ikan Karang di Kepulauan Seribu. Prosiding Konferensi Nasional (KONAS) V, Pesisir, Laut dan Pulau-pulau Kecil.

Wood, E.M. 1985. Exploitation of Coral Reef Fishes for The Aquarium Trade. Marine Conservation Society, Herefordshire, United Kingdom.

Wood, E.M. 2001. Collection of Coral Reef Fish for Aquaria: Global Trade, Conservation Issues and Management Strategies. Marine Conservation Society, Herefordshire, United Kingdom.

Yayasan Terumbu Karang Indonesia. 2004. Activity Report : Marine Ornamental Certification in Panggang Island, Seribu Islands. Yayasan Terumbu Karang Indonesia, Jakarta: 31 pp. 